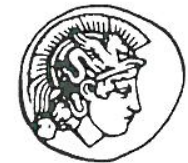

PERGAMON

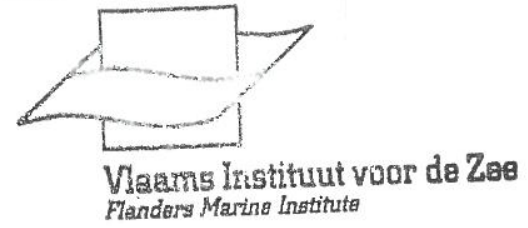

Flanders Maring Institute

\title{
The role of the benthic biota in sedimentary metabolism and sediment-water exchange processes in the Goban Spur area (NE Atlantic)
}

\author{
C.H.R. Heip ${ }^{a, *}$, G. Duineveld ${ }^{b}$, E. Flach ${ }^{a}$, G. Graf ${ }^{c, 1}$, W. Helder ${ }^{b}$,
} P.M.J. Herman ${ }^{\mathrm{a}}$, M. Lavaleye ${ }^{\mathrm{b}}$, J.J. Middelburg ${ }^{\mathrm{a}}$, O. Pfannkuche ${ }^{\mathrm{c}}$, K. Soetaert ${ }^{\mathrm{a}}$, T. Soltwedel ${ }^{\mathrm{d}}$, H. de Stigter ${ }^{\mathrm{b}}$, L. Thomsen ${ }^{\mathrm{c}}$, J. Vanaverbeke ${ }^{\mathrm{e}}, \mathrm{P}$. de Wilde ${ }^{\mathrm{b}}$

${ }^{\mathrm{a}}$ NIOO-CEMO, P.O. Box 140, 4400 AC Yerseke, Netherlands

${ }^{\mathrm{b}}$ NIOZ, P.O. Box 59, 1790 AB Den Burg, Texel, Netherlands

${ }^{\mathrm{c}}$ GEOMAR, Wishhofstraße 1-3, D-24148 Kiel, Germany

d AWI, P.O. Box 120161, D-27515 Bremerhaven, Germany

${ }^{\mathrm{e}}$ University of Gent, K.L. Ledeganckstraat 32, B-9000 Gent, Belgium

\begin{abstract}
We provide an overview of the role of biological processes in the Benthic boundary layer (BBL) and in sediments on the cycling of particulate organic material in the Goban Spur area (Northeast Atlantic). The benthic fauna, sediment and BBL characteristics were studied along a transect ranging from 208 to $4460 \mathrm{~m}$ water depth in different seasons over 3 years.

Near-bottom flow velocities are high at the upper part of the slope (1000-1500 m), and high numbers of filter-feeding taxa are found there such that organic carbon normally passing this area during high flow conditions is probably trapped, accumulated, and/or remineralised by the fauna.

Overall metabolism in shelf and upper slope sediments is dominated by the macrofauna. More than half of the organic matter flux is respired by macrofauna, with a lower contribution of metazoan meiofauna $(4 \%)$ and anoxic and suboxic bacterial mineralisation (21\%); the remainder $(23 \%)$ being channelled through nanobiota and oxic bacteria. By its feeding activity and movement, the macrofauna intensely reworks the sediments on the shelf and upper slope. Mixing intensity of bulk sediment and of organic matter are of comparable magnitude.

The benthos of the lower slope and abyssal depth is dominated by the microbiota, both in terms of total biomass $(>90 \%$ ) and carbon respiration (about $80 \%$ ). The macrofauna $(16 \%)$, meiofauna $(4 \%)$ and megafauna $(0.5 \%)$ only marginally contribute to total carbon respiration at depths below $1400 \mathrm{~m}$. Because large animals have a lower share in total metabolism, mixing of organic matter within the sediments is reduced by a factor of 5 , whereas mixing of bulk sediment is one to two orders of magnitude lower than on
\end{abstract}

*Corresponding author. Tel.: +31-113-577445; fax: + 31-113-573616.

E-mail address: heip@cemo.nioo.knaw.nl (C.H.R. Heip).

' Present Address: University of Rostock, Freiligrathstraße 7/8, D-18055 Rostock, Germany. 
the shelf. The food quality of organic matter in the sediments in the shallowest part of the Goban Spur transect is significantly higher than in sediments in the deeper parts. The residence time of mineralisable carbon is about $120 \mathrm{~d}$ on the shelf and compares well with the residence time of the biota. In the deepest station, the mean residence time of mineralisable carbon is more than $3000 \mathrm{~d}$, an order of magnitude higher than that of biotic biomass. (C) 2001 Published by Elsevier Science Ltd.

\section{Introduction}

Sediments are an important component in global biogeochemical cycles, and benthic fauna play a major role in determining their geochemical behaviour. Suspension-feeding fauna actively remove particles from the water column and deposit it as faeces either within or on top of the sediment, a process called biodeposition (Graf and Rosenberg, 1997). Feeding pits, faecal pellet mounds, and tube-structures of the benthos locally can change the current regime and cause resuspension and passive biodeposition of particles (Carey, 1983; Jumars and Nowell, 1984; Miller et al., 1984). Bioturbation due to moving animals or due to bulk feeding by deposit feeders substantially modifies the physical and geochemical properties of sediments (Boudreau, 1994; Gage and Tyler, 1991; Soetaert et al., 1996a, b).

The organic fraction of the particle input to the sediment is a potential energy source for benthic organisms. It is remineralised, and carbon dioxide and nutrients are produced and flow back into the pelagic system (Wassmann, 1990). Part of the organic matter is not remineralised and is buried in the sediment preventing return of its degradation products to the pelagic system. Therefore, the mineralisation of organic matter through respiratory processes is an important aspect of the global ocean carbon cycle.

Benthic mineralisation processes can be modelled by means of early diagenetic models, which describe the sediment depth profiles of organic carbon, oxygen and nutrients (e.g., Berner, 1980; van Weering et al., 2001). These models allow to quantify the relative importance of the various competing pathways (oxic mineralisation, denitrification, sulphate reduction, etc.) in total mineralisation, the direction and magnitude of sediment-water exchanges of solutes, the intensity of mixing, and even the food quality (Soetaert et al., 1998). The activity of animals is largely parameterised in these models. The impact of animal movement and feeding is represented by a bioturbation coefficient (Boudreau, 1986), and respiration is modelled as a first-order decay of organic matter. Obviously, these are simplifications which only schematically represent the complexity of benthic biological processes.

An alternative approach to assess benthic respiration is by looking at the actors, the benthic animals and bacteria. Respiration by the various benthic groups can be estimated based on weight-specific allometric relationships (Mahaut et al., 1995). Although estimating animal biomass may be tedious and time-consuming, it is necessary for an adequate partitioning of total system respiration in the different biotic categories, which may be instructive as to the recycling capacity and residence time of organic matter in the sediments.

In the OMEX project, the general aim was to study the physical, chemical and biological processes at ocean margins - the shelf break and the continental slope-that determine the transport of material from the shelf to the deep sea. The aim of the subproject Benthic Biology 
within OMEX was to evaluate the role of biological processes in the benthic boundary layer and in the sediments in the cycling of particulate organic material. Both the geochemical approach and a unique opportunity to understand the fun margin sediments were adopted, therefore, offering ocean.

In this synthesis paper we focus on the role of benthic animals in sedimentary metabolism and benthic-pelagic coupling. We briefly summarise information on the benthic community already Flach et al., 1998, 1999; from the project (Duineveld et al., 1997; Flach and Heip, 1996a, b; Flach, 1997; Vanaverbeke et al., 1997). The fl, 1998; Soetaert et al., 1996c, 1997; Thomsen and compartments is assessed by re-evaluating the available data.

This paper, therefore, describes euphotic zone (Joint et al., 2001), sinks ultimate fate of organic matter that originates in the et al., 2001), and is deposited on the sediments water column (Antia et al., 1999; Herman van Weering et al. (2001), where emphasis of the Goban Spur area. In contrast to the paper of sediment, our paper centres mainly around the biogeochemical and geological aspects of the

\section{Material and methods}

\subsection{Study site}

The OMEX-transect (Fig. 1, Table 1) is situated at the Goban Spur area in the NE Atlantic, reaching from the continental shelf of the Celtic Sea (Station A, $208 \mathrm{~m}$ ), along the continental slope, down to the Porcupine Abyssal Plain (Station E, $4460 \mathrm{~m}$ ). Bottom-water temperature decreased from $\sim 11^{\circ} \mathrm{C}$ at the shallowest stations $(\sim 200 \mathrm{~m})$ to $\sim 2.5^{\circ} \mathrm{C}$ at the deepest stations $(\sim 4 \mathrm{~km})$. The bottom water was well oxygenated $\left(200-300 \mu \mathrm{moll}^{-1}\right)$; lowest oxygen concentraSamples observed at around 1000-m depth (van Weering, 1994).

Median percentage of $\mathrm{CaCO}_{3}$ increased with $\sim 95 \mu \mathrm{m}$ at $208 \mathrm{~m}$ to $\sim 8 \mu \mathrm{m}$ below $2000 \mathrm{~m}$, and the $\sim 4000 \mathrm{~m}$ (Flach and Heip, 1996a). Sediments water depth from $\sim 20 \%$ at $208 \mathrm{~m}$ to $\sim 70 \%$ at stations (Flach and Heip, 1996a), and no changes in sediment composition beth $15 \mathrm{~cm}$ at all were observed (Flach and Heip, 1996b). The organic content of the sediment between the 3 years between about $0.1 \%$ and $0.7 \% \mathrm{C}$ in the upper $1 \mathrm{~cm}$ (Lohse et al., 1998).

\subsection{Benthic boundary layer ( $B B L$ ) characteristics}

Water samples at 5, 10, 20 and $40 \mathrm{~cm}$ height above sea floor were taken with the BIOPROBE bottom-water sampler (Thomsen et al., 1994) during five cruises to Goban Spur in October 1993, January, May and September 1994, and August 1995. Flow velocity in the BBL was measured with a thermistor flow meter at $30-\mathrm{cm}$ height above bottom (ADM Instruments) and by analysis of pictures obtained by the particle cameras. A normal launch involved lowering the instrument system to the sea floor using a single conductor cable (10-mm diameter, $200 \mathrm{~g} \mathrm{~m}^{-1}$ in water) 

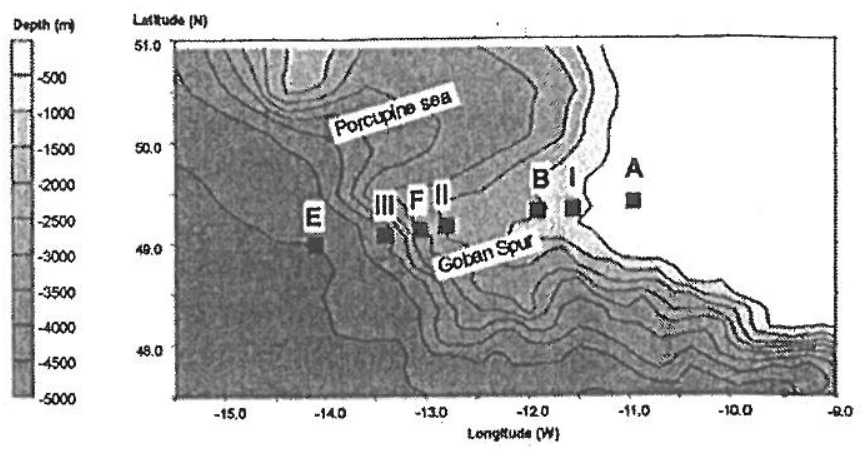

Goban Spur transect

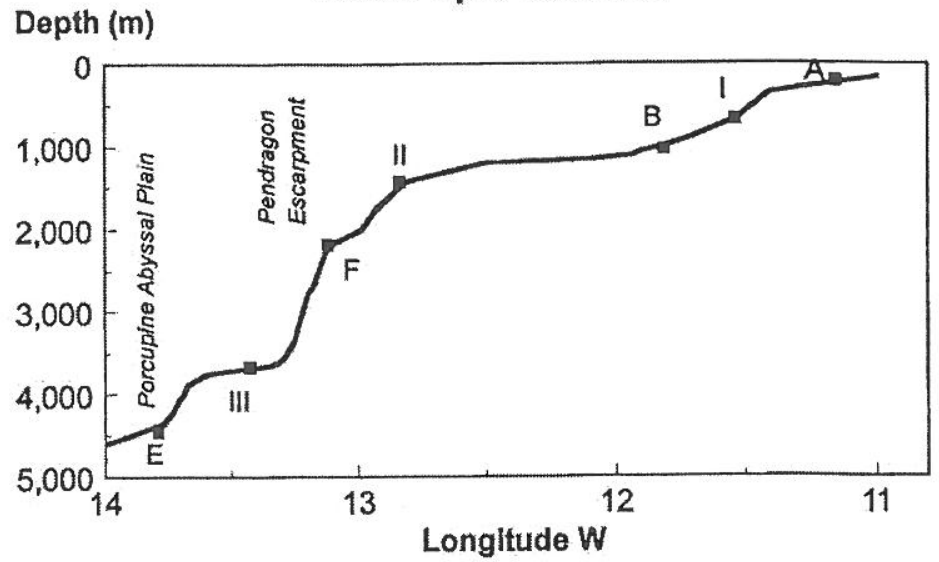

Fig. 1. Location of the OMEX transect and sampling stations.

monitoring flow velocity, light transmission in the BBL, compass direction (position), and battery capacity of BIOPROBE.

Particulate organic carbon (POC) of water was measured with a Heraeus CHN-Analyser after removal of calcium carbonate. Chloroplastic pigment equivalents (CPE) were analysed spectrofluorometrically with a Turner-Designs Fluorometer and calculated using the equations of Lorenzen (1967). Total particulate matter (TPM) was determined using the method of Bodungen et al. (1991).

\subsection{Benthic density and biomass}

Density values of the different faunal groups were compared for May 1994 when data were available for all of them except the megafauna (all stations), which was sampled only in August 1995. Biomass values were averaged over all samples that were obtained (see Table 1). In view of the different numbers of samples, no attempt was made to attribute errors to these values.

The biomass of the smallest benthic organisms (bacteria, protozoans, and a small fraction of the meiofauna) was assessed by analysis of phospholipid concentration (indicative of cell-wall 
Table 1

Sampling stations and data used ${ }^{\mathrm{a}}$

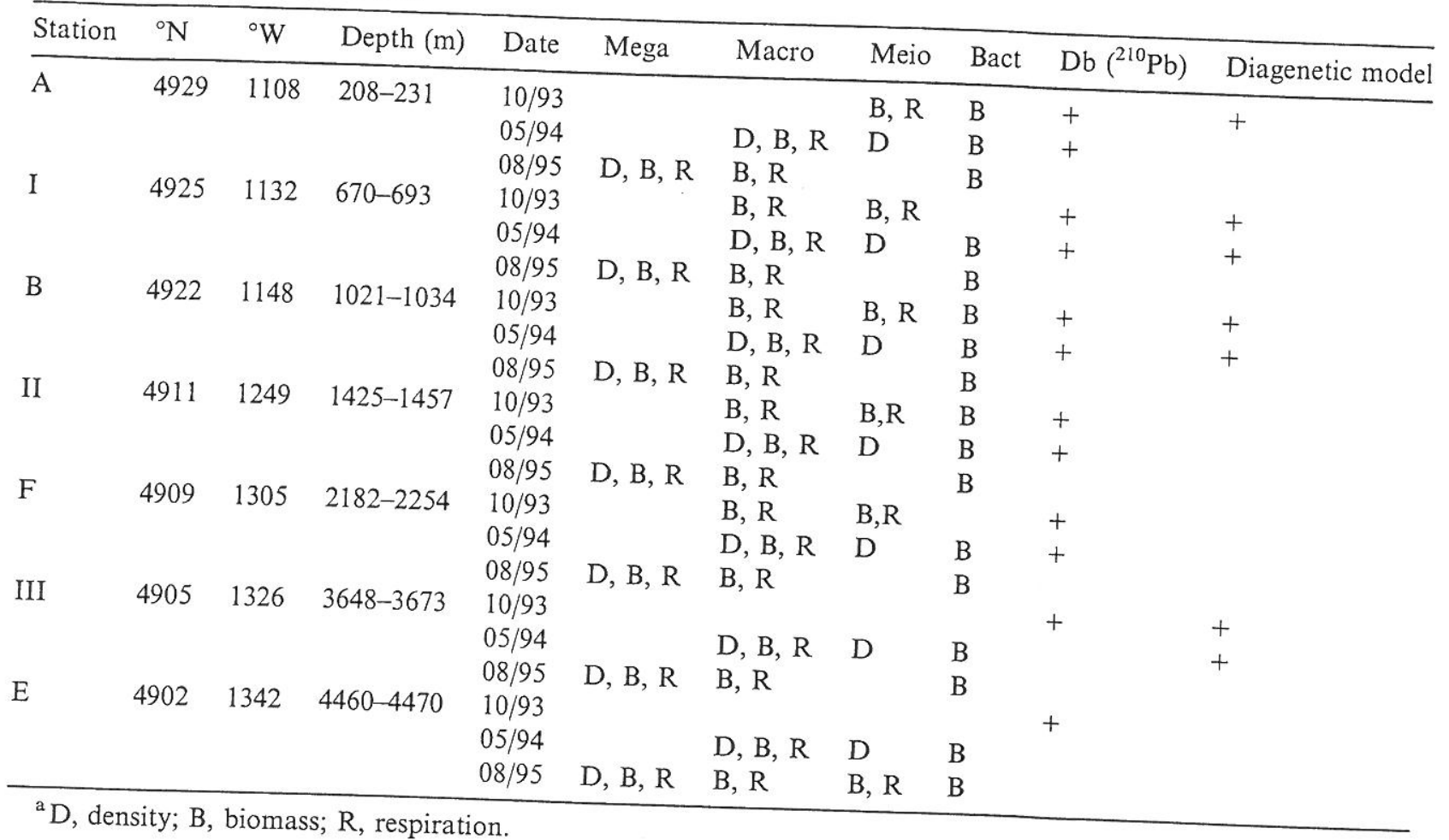

material) from five replicate samples per station for each sampling date (Soltwedel, 1997). $\mathrm{P} \mathrm{cm}^{-3}=0.1 \mathrm{~g} \mathrm{C} \mathrm{m}^{-2}$ for each $\mathrm{cm}$ converted to biomass using the conversion $100 \mu \mathrm{mol}$ who assumed $100 \mu \mathrm{mol} \mathrm{Pg} \mathrm{C} \mathrm{P}^{-1}$ for prokaryotes).

Sediment samples for fauna

Institute of Sea Research (NIOZ). different sizes were taken at differ . Because of logistic reasons different numbers of boxes of the shallow stations) and $50 \mathrm{~cm}$, both stations. Boxcores with a diameter of $30 \mathrm{~cm}$ (mainly used at the study of living benthic foraminith a top valve to prevent leakage, were used. For sampling station in May 1994, by box core until at least $10 \mathrm{~cm}$, by carefully inserting a PVC tube of 9-cm inner diameter into the meiofauna was taken un $\mathrm{cm}^{2}$ as described by Flach et al. (1998). One subsample for the (Vanaverbeke et al., 1997), 1999). Station III was not the values of Stations F and E. Density was data shown in Figs. 4 and 5 are interpolations from following Heip et al. (1985), and nematos estimated as described in Vanaverbeke et al. (1997) (Andrassy, 1956), assuming a carbon-to-we biomass was calculated from Andrassy's formula

For macrofaunal analysis, the boxcoretweight ratio of 0.125 (Vanaverbeke et al., 1997). and Heip, 1996a). This sieve size is larger thanles were sliced and sieved on a $0.5-\mathrm{mm}$ sieve (Flach 
was chosen to decrease overlap with the meiofauna fraction and because of a very considerable time gain in the analysis. Flach (unpublished) compared samples washed through 0.5 and $0.3 \mathrm{~mm}$ sieves and found a consistent difference along the transect of about $40 \%$ in density estimates but no significant difference in biomass and respiration estimates. The macrofaunal taxa were divided in carnivores/scavengers, filter-feeders (feeding from the water column), interface-feeders (which can switch from filter-feeding to deposit-feeding; Taghon and Greene, 1992), surface and subsurface deposit-feeders. Feeding-types were determined on the smallest taxonomic level possible (see Flach et al., 1998). Biomass values were converted into organic C-content per major taxon using the conversion factors given by Rowe (1983). The megafauna was sampled quantitatively in August 1995 with a 3.5-m Agassiz trawl (see Duineveld et al., 1997). The mesh width of the net was $1 \mathrm{~cm}$. When possible the animals were identified down to species. As a lower arbitrary size limit for megafauna, we used the definition of Rutgers van der Loeff and Lavaleye (1986), i.e. an animal must have a diameter of at least $1 \mathrm{~cm}$ or weigh at least $50 \mathrm{mg}$ (blotted wet weight). The animals were divided according to feeding guilds into deposit-feeders, filter-feeders and carnivores. Demersal fish, living close to the sea floor (within $1 \mathrm{~m}$ ), were included in the megabenthos.

\subsection{Benthic respiration}

Sediment community oxygen consumption (SCOC) was measured in situ and in decompressed cores on board (see Duineveld et al., 1997). For the shipboard measurements two intact boxcore samples of $30-\mathrm{cm}$ diameter were used. After sealing the incubation cores with a lid holding a stirrer and $\mathrm{O}_{2}$ probes (Yellow Spring Instr.), they were transferred to a thermostatically controlled incubator set at bottom temperature. The $\mathrm{O}_{2}$ decrease in the overlying water was continuously recorded. The initial linear decrease of $\mathrm{O}_{2}$ was used for calculating SCOC. In situ measurements of SCOC were made with a free-falling benthic lander, the BOLAS, as described by Tahey et al. (1996).

The respiration of the various faunal groups was estimated based on mean individual dry weight using a power law (Mahaut et al., 1995):

$$
R=a W^{b}
$$

where $R$ is the respiration rate of an individual $\left(\mathrm{d}^{-1}\right), W$ the biomass in $\mathrm{mg}$. The individual rates were summed up over all individuals in the sample and extrapolated to a $1 \mathrm{~m}^{2}$ surface area.

For the macro-and megafauna, respiration rates, valid at temperatures of $2-4^{\circ} \mathrm{C}$, were estimated as:

$$
R=0.0074 W^{-0.24}
$$

Corrections for temperature were made using Krogh's "normal curve" (Winberg, 1971). Annual respiration of the macrofauna was calculated out of the three different seasons.

Nematode respiration, valid at $20^{\circ} \mathrm{C}$, was estimated as:

$$
R=0.0164 W^{-0.1456}
$$

(de Bovée and Labat, 1993; Soetaert et al., 1997). Conversion to the in situ temperatures was done assuming a $Q_{\text {ro }}$ value of 2 (Soetaert et al., 1997). 
The respiration of the small biota (bacteria and protozoans) was estimated as the difference between total SCOC rates and respiration rate of the metazoan organisms.

\subsection{Food quality}

The total amount of mineralisable organic matter ("food") in the sediment can be estimated based on the diagenetic modelling results of Herman et al. (2001), using the method outlined in organisms, although they constitute totally refractory compounds as they are not consumed by short, the degradability of organic the largest component of carbon below, say, 5-cm depth. In modelling oxygen, nitrate, ammonium atter settling on the sediment surface was assessed by mean degradability of mineralisable and organic carbon versus sediment depth profiles. The integrating its concentration over the entire sediment in the sediment was then calculated by

\section{Results}

\subsection{Densities}

In May 1994, living Foraminifera decreased from $\sim 10 \mathrm{~cm}^{-2}\left(1 \times 10^{5} \mathrm{~m}^{-2}\right)$ at the shelf to less was observed at the mid-slope station of the slope (Fig. 2; Table 2). A secondary peak in density et al., 1998). Meiofaunal densities from 423 per $10 \mathrm{~cm}^{2}\left(4 \times 10^{5} \mathrm{~m}^{-2}\right)$ at station A similar along the whole depth range, ranging Meiofauna mainly consisted of Nematoda (88 A to 649 per $10 \mathrm{~cm}^{2}\left(6 \times 10^{5} \mathrm{~m}^{-2}\right)$ at St. II. densities strongly decreased with increasing (88-95\%) (Vanaverbeke et al., 1997). Macrofaunal about $500 \mathrm{~m}^{-2}$ at the two deepest stations. water depths, from about $8000 \mathrm{~m}^{-2}$ at the shelf to stations, although their relative share dens. Polychaetes were the most abundant taxon at all shelf to $\sim 40-50 \%$ at mid-slope depths ansed with increasing water depth from $\sim 75 \%$ at the

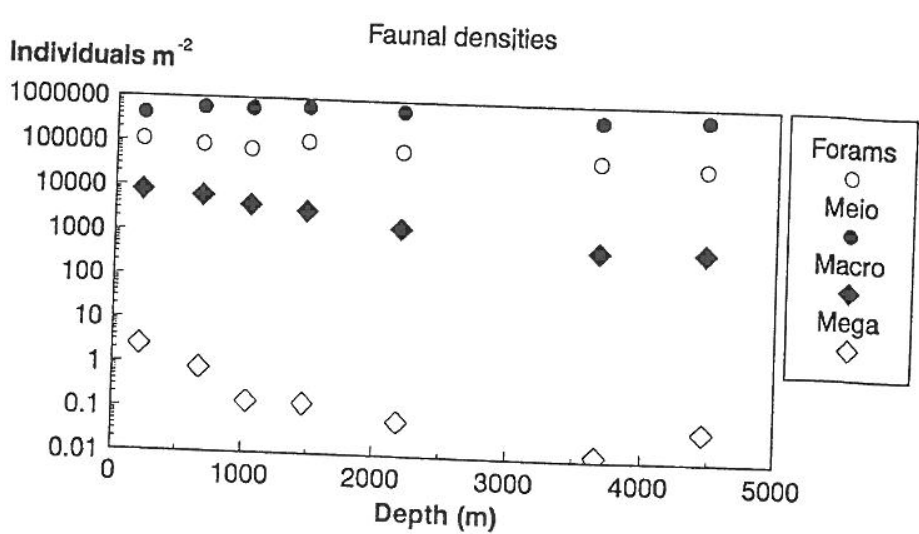

Fig. 2. Densities of the various benthic taxa in May 1994 (except for the megafauna, which was sampled in August
1995). 
Table 2

Densities per $\mathrm{m}^{2}$ of different faunal groups in 1994 (Megafauna in August 1995)

\begin{tabular}{lccccc}
\hline Station & Depth & Forams & Meio & Macro & Mega \\
\hline A & 208 & 107800 & 423000 & 7980 & 2.478 \\
I & 670 & 87000 & 589000 & 6169 & 0.782 \\
B & 1034 & 71400 & 578000 & 3952 & 0.143 \\
II & 1465 & 110400 & 649000 & 3062 & 0.133 \\
F & 2182 & 76400 & 603000 & 1413 & 0.059 \\
III & 3670 & 53800 & 446000 & 518 & 0.013 \\
E & 4460 & 42600 & 529000 & 542 & 0.049 \\
\hline
\end{tabular}

(Flach and Heip, 1996a). Megafaunal densities (in August 1995) also decreased with increasing water depths, from $\sim 2500$ per $1000 \mathrm{~m}^{2}\left(2.5 \mathrm{~m}^{-2}\right)$ at the shelf to $\sim 50$ per $1000 \mathrm{~m}^{2}\left(0.05 \mathrm{~m}^{-2}\right)$ at the lower part of the slope. On the shelf Ophiuroidea dominated the megafauna, whereas at the deeper stations Holothuroidea were more abundant (Duineveld et al., 1997).

The different rates of decrease in abundance of the different faunal groups with increasing water depths resulted in different community structures at different depths. Megafauna decreased faster than macrofauna, whereas macrofauna and foraminiferans decreased faster than metazoan meiofauna. With increasing water depths benthic communities thus become more dominated by smaller taxa.

\subsection{BBL characteristics and feeding characteristics of the macrofauna}

In Fig. 3 the variation of total density of filter- and interface-feeders with station depth is compared with several independent variables measured in the water of the benthic boundary layer (concentrations at $5 \mathrm{~cm}$ above the bottom of total particulate matter, TPM, particulate organic carbon (POC), chloroplastic pigment equivalent (CPE) and flow velocity at $30 \mathrm{~cm}$ above the bottom; see material and methods). Most variables are negatively correlated with station depth; the correlation is better after log-transformation than for the arithmetic values. The correlation coefficients of POC $(p=0.08)$ and CPE concentrations $(p=0.16)$ with water depth are not significant. Due to this general depth-dependence of all variables, the correlation between environmental variables and density of filter- (+ interface-) feeders was investigated using partial correlation coefficients, correcting for depth as a common variable (Sokal and Rohlf, 1995). Only CPE concentration showed a marginally significant partial correlation with density of filter- and interface-feeders $\left(r_{12,3}=0.86, n=6, p=0.06\right)$. The probability level of the other partial correlation coefficients was $>0.5$.

\subsection{Biomass}

The biomass of the different benthic groups is given in Table 3. The average value and the relative share in the total biomass are shown in Fig. 4. The microbiota (bacteria and protists) dominated everywhere; they contributed more than $75 \%$ to the total biomass in the three shallowest stations ( $<1050 \mathrm{~m}$; stations A, I, B), about $90 \%$ or more in the deeper stations. The 

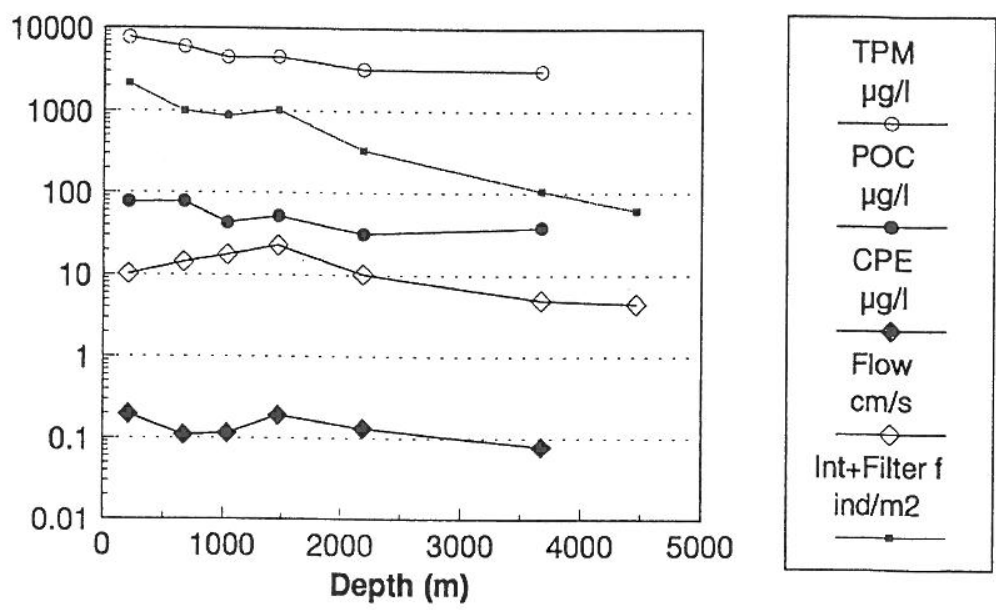

Fig. 3. Total particulate matter (TPM, $\mu \mathrm{g}^{-1}$ ), particulate organic carbon (POC, $\mu \mathrm{g} 1^{-1}$ ), chloroplastic pigment equivalents (CPE, $\left.\mu \mathrm{gl}^{-1}\right)$, flow velocity $\left(\mathrm{cm} \mathrm{s}^{-1}\right)$ and density of filter- and interface feeders (ind $\mathrm{m}^{-2}$ ) versus water depth.

Table 3

Mean concentration at $5 \mathrm{~cm}$ above the bottom in the BBL of total particulate matter (TPM), Particulate organic carbon (POC) and Chlorophyll pigment equivalents (CPE). Mean flow velocity $30 \mathrm{~cm}$ above the bottom (Flow). Density of filterfeeders and interface feeders (individuals $\mathrm{m}^{-2}$ )

\begin{tabular}{|c|c|c|c|c|c|c|c|}
\hline Station & Depth (m) & $\begin{array}{l}\text { TPM } \\
\left(\mathrm{mg} \mathrm{l}^{-1}\right)\end{array}$ & $\begin{array}{l}\text { POC } \\
\left(\mu \mathrm{g}^{-1}\right)\end{array}$ & $\begin{array}{l}\mathrm{CPE} \\
\left(\mu g 1^{-1}\right)\end{array}$ & $\begin{array}{l}\text { Flow } \\
\left(\mathrm{cm} \mathrm{s}^{-1}\right)\end{array}$ & $\begin{array}{l}\text { Filter feeders } \\
\text { (ind } \mathrm{m}^{-2} \text { ) }\end{array}$ & $\begin{array}{l}\text { Interface feeders } \\
\text { (ind } \mathrm{m}^{-2} \text { ) }\end{array}$ \\
\hline A & 208 & 7.7 & 77 & 0.196 & 10.2 & 826 & 1334 \\
\hline I & 670 & 6 & 77.5 & 0.109 & 14.25 & 534 & 459 \\
\hline B & 1034 & 4.45 & 43 & 0.115 & 17.5 & 532 & 343 \\
\hline II & 1425 & 4.5 & 51.5 & 0.191 & 22.75 & 532 & 500 \\
\hline $\mathrm{F}$ & 2182 & 3.2 & 31.5 & 0.132 & 10.15 & 201 & 129 \\
\hline III & 3670 & 3.1 & 38 & 0.079 & 5 & 35 & 71 \\
\hline $\mathrm{E}$ & 4460 & & & & 4.5 & 61 & 0 \\
\hline
\end{tabular}

macrofauna was the second most important group. About $10 \%$ of total biomass was due to small macrofauna on the stations below $100 \mathrm{~m}$ (stations A, I, B). Some exceptionally large animals (1 Pennatulacea and 1 Sipunculida at station B in May 1994; 2 Echinoidea at station A in August 1995, 1 Holothuroidea at station E in May 1994) contributed 10\% to total biomass at these stations (called "large macrofauna" in some tables and figures). As these animals are not quantitatively estimated by the sampling procedure, they were considered separately. Both the meio- and megafauna were unimportant in terms of biomass (about $1 \%$ on average; Fig. 4).

In general the biomass of all benthic groups was lower in the deep stations than on the shelf (Fig. 4), but only nematode biomass exhibited a monotonous decline with depth (Vanaverbeke et al., 1997): The highest microbial biomass was observed at station II (1420 m). Macrofaunal biomass was rather constant at the shelf and upper slope $(<1050 \mathrm{~m}$; stations A, I, B) and was 

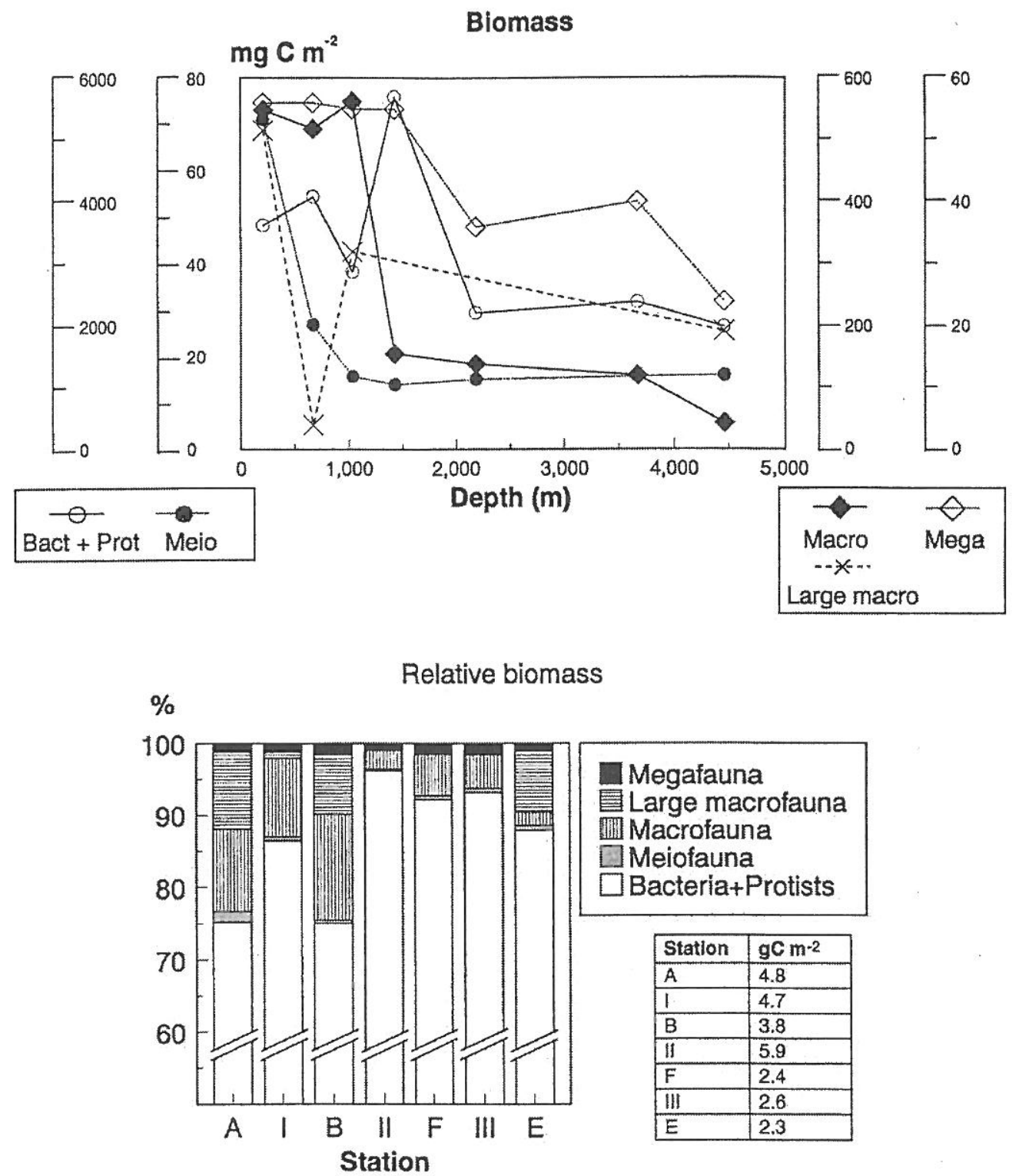

Fig. 4. (a) Biomass of the various taxa, (averaged over all sampling dates, see Table 1); (b) relative share of the various taxa.

significantly depressed below that depth. Similarly, megafaunal biomass was about double at the shelf and upper slope stations ( $<1500 \mathrm{~m}$; stations A, I, B, II). However, when calculated in wet weight a peak in megafauna biomass was observed at mid-slope station II (Duineveld et al., 1997), due to a high abundance of large sponges (Porifera).

Using the results of the diagenetic model (Herman et al., 2001; Soetaert et al., 1998), the total amount of mineralisable carbon (food) in the sediment was estimated to be about 4, 10, 27 and $39 \mathrm{gC} \mathrm{m}^{-2}$ at stations A, I, B, and III, respectively (Table 4). 
Table 4

Biomass ( $\mathrm{mg} \mathrm{C} \mathrm{m}^{-2}$ ) of biota on the Goban Spur, amount of mineralisable carbon $\mathrm{Cmin}\left(\mathrm{mg} \mathrm{C}^{-2}\right)$ and $\%$ of $\mathrm{Cmin}$ consisting of biota

\begin{tabular}{|c|c|c|c|c|c|c|c|c|c|}
\hline Station & Depth & Micro & Meio & Macro small & Macro large & Mega & Total biota & $\mathrm{Cmin}$ & $\begin{array}{l}\% \mathrm{Cmin} \\
\text { in biota }\end{array}$ \\
\hline A & 208 & 3623 & 71 & 549 & 516 & 56 & 4815 & 4439 & 100 \\
\hline I & 670 & 4083 & 27 & 518 & 40 & 56 & 4724 & 9548 & 49 \\
\hline B & 1034 & 2877 & 16 & 562 & 320 & 55 & 3830 & 27358 & 14 \\
\hline II & 1425 & 5699 & 14 & 155 & 0 & 55 & 5923 & & \\
\hline $\mathrm{F}$ & 2182 & 2220 & 15 & 138 & 0 & 36 & 2409 & & \\
\hline III & 3670 & 2388 & 15 & 121 & 0 & 40 & 2564 & 38654 & 7 \\
\hline $\mathrm{E}$ & 4460 & 1989 & 16 & 43 & 192 & 24 & 2264 & & \\
\hline
\end{tabular}

\subsection{Carbon mineralisation}

Total carbon mineralisation rates, calculated from SCOC, measurements decreased with increasing water depth, from about $13 \mathrm{~g} \mathrm{C} \mathrm{m}^{-2} \mathrm{a}^{-1}$ at the shelf to about $2.5 \mathrm{~g} \mathrm{C} \mathrm{m}^{-2} \mathrm{a}^{-1}$ in the abyss (Duineveld et al., 1997; Soetaert et al., 1997) (Table 4). Carbon mineralisation due to respiration of the benthic metazoans also decreased with increasing water depth, from $\sim 8 \mathrm{gC} \mathrm{m}^{-2} \mathrm{a}^{-1}$ at the shelf station to $0.7 \mathrm{gC} \mathrm{m}^{-2} \mathrm{a}^{-1}$ at the deepest station. Animal respiration decreased monotonously with water depth for all metazoan groups (Fig. 5). Bacterial and protozoan respiration was high at station II (1420-m depth), in accordance with higher biomass there.

The respiration rates per unit biomass varied between $2.3-3.5 \% \mathrm{~d}^{-1}, 0.9-2.8 \% \mathrm{~d}^{-1}$ and $0.1-0.2 \% \mathrm{~d}^{-1}$ for nematodes, macrofauna and megafauna, respectively, reflecting the size dependence (Table 5). Turnover rates calculated for bacteria and protozoa were significantly lower, ranging from 0.2 to $0.4 \% \mathrm{~d}^{-1}$. Because of the small size of the microbiota, much higher turnover rates were expected (about two orders of magnitude higher), indicating that a significant proportion of microbial biomass was probably dormant in the sediment. Turnover times of the total mineralisable carbon in the sediment decreased from $0.82 \% \mathrm{~d}^{-1}$ to $0.03 \% \mathrm{~d}^{-1}$ (Table 5).

Some $50-60 \%$ of the carbon mineralisation on the shelf and upper slope was due to metazoans, whereas at greater water depth, only $\sim 20 \%$ of the carbon mineralisation was due to multicellular organisms (Table 5, Fig. 5). Metazoan respiration was dominated by the macrofauna at all depths (Fig. 5).

\section{Discussion}

\subsection{Benthic community structure}

The size of benthic biota covers several orders of magnitude, from micrometres (bacteria) to decimetres (megafauna). Because metabolism is weight dependent (Mahaut et al., 1995), smaller organisms have relatively higher metabolic requirements, which may affect the degree to which food is recycled in the benthic food chain. Sediment mixing is more impacted by the movement of 


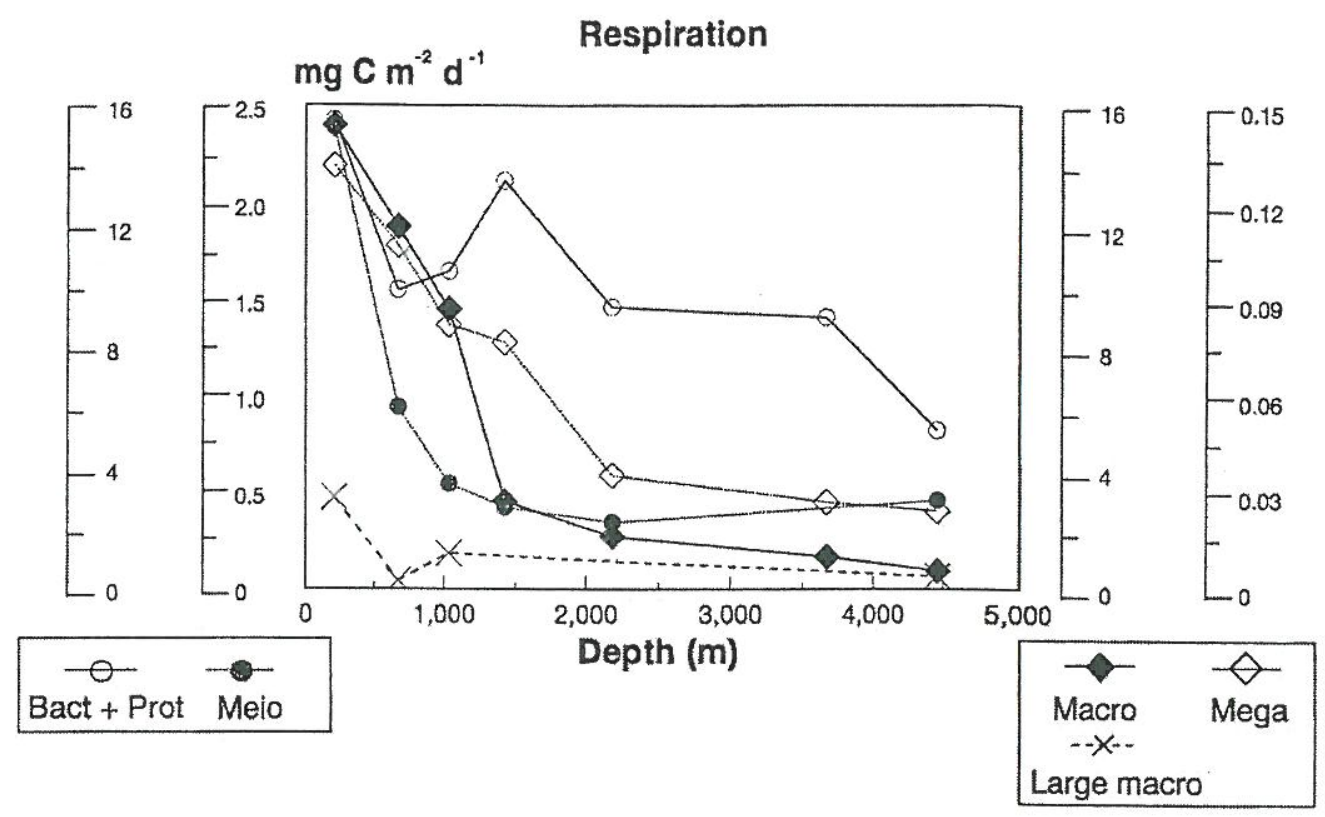

$\% \quad$ Relative respiration

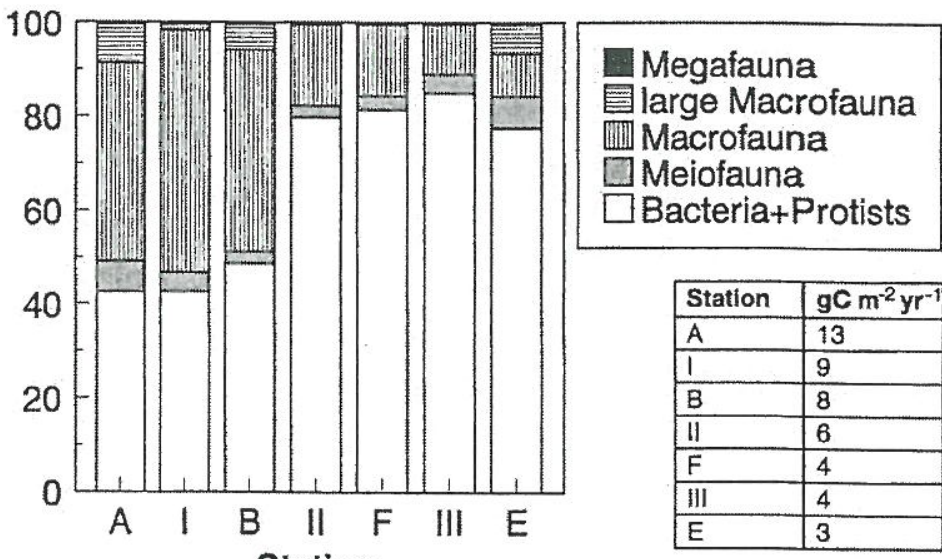

Fig. 5. (a) Respiration of the various benthic taxa, (averaged over all sampling dates, see Table 1); (b) relative share of the various taxa.

big rather than small animals (Wheatcroft et al., 1990), and larger animals may in addition alter the geochemistry of the sediment by ventilation (Aller, 1984) and biodeposition. Hence, the size distribution of benthic organisms may strongly determine the recycling of organic matter in the sediments. Nevertheless, for logistic reasons it is very difficult to obtain estimates of the importance of benthic groups covering the entire size spectrum, and there are consequently few data covering the ocean margin (Rowe et al., 1991; Eldridge and Jackson, 1993; Piepenburg et al., 1995; Mahaut et al., 1995). 
Table 5

Daily respiration ( $\mathrm{mg} \mathrm{Cm}^{-2} \mathrm{~d}^{-1}$ ) of different biota and sediments

\begin{tabular}{lcccclllll}
\hline Station & Depth & Micro & Meio & Macro small & Macro large & Mega & SCOC & \% Micro biota & \% Meta- zoans \\
\hline A & 208 & 15.5 & 2.4 & 15.3 & 3.1 & 0.1 & 36.4 & 42.6 & 57.4 \\
I & 670 & 9.9 & 0.9 & 12.0 & 0.3 & 0.1 & 23.2 & 42.7 & 57.3 \\
B & 1034 & 10.5 & 0.5 & 9.3 & 1.2 & 0.1 & 21.6 & 48.6 & 51.4 \\
II & 1425 & 13.5 & 0.4 & 2.9 & 0.0 & 0.1 & 16.9 & 79.9 & 20.1 \\
F & 2182 & 9.4 & 0.3 & 1.8 & 0.0 & 0.0 & 11.5 & 81.7 & 18.3 \\
III & 3670 & 8.6 & 0.4 & 1.1 & 0.0 & 0.0 & 10.1 & 85.1 & 14.9 \\
E & 4460 & 5.3 & 0.5 & 0.6 & 0.4 & 0.0 & 6.8 & 77.9 & 22.1 \\
\hline
\end{tabular}

In this study, we combined quantitative estimates of the micro-, meio-, macro-, and megafauna at several stations along a depth transect in the Goban Spur area. The approaches adopted for measuring biomass of each benthic group were different and this may in part bias our results. For instance, there may be some overlap between bacterial and protozoan biomass estimates (based on a biochemical assay) and nematode biomass estimates (based on length-weight conversions after sorting) (Soltwedel, 1997). However, nematode biomass is only a tiny fraction of the microfaunal biomass, and therefore, there is no need to correct for this potential overlap. Microfaunal biomass was measured by phospholipid concentrations, a method that is well documented in deep-sea research (Soltwedel, 1997), but independent confirmation through direct cell counting or other methods was not available. Moreover, microbiota biomass values are given for the first $5 \mathrm{~cm}$ of the sediment only and no attempt was made to correct for deeper occurring biomass. Macrofaunal sampling strategy was adequate to survey the small animals, at the expense of equally good quantitative data of the larger macrofauna. Occasionally, an exceptionally large animal was present in the macrofaunal samples, and this was considered separately in the subsequent presentation of results.

One of the striking results of this study is the dichotomy between the shelf-upper slope stations dominated by metazoan and especially macrofaunal metabolism and the deep slope stations dominated by microbial metabolism, even though the microbial biomass is high everywhere. Respiration estimates of the various metazoan groups were based on an allometric regression with body weight, whereas the microfaunal contribution was assessed by difference between total sediment mineralisation rates (based on SCOC measurements) and metazoan respiration. Because of that, the budget is closed by an unknown term (microbial respiration), and therefore, it is impossible to assess the accuracy of our estimates. A possible artefact could relate to the assumed temperature dependence of respiration rates. If the depression of metazoan respiration at low temperature would be overestimated, this would give too much weight to bacterial respiration at depth. However, the dichotomy between upper and lower slopes in the respiration estimates does not reflect temperature differences, which decreases more gently from the shelf station $\left(11^{\circ} \mathrm{C}\right)$ to the deep station $\left(2^{\circ} \mathrm{C}\right)$. Also, the similarity in the pattern of microbial respiration and biomass, e.g., the conspicuously large value at 1420 -m water depth, is encouraging and lends validity to the estimates obtained (Figs. 3 and 5).

Furthermore, the meiobenthos and megabenthos data were obtained from one sampling occasion, whereas data for the macro- and microbenthos biomass were pooled from three 
campaigns, possibly aliasing seasonality with observed trends. Notwithstanding these caveats, our results seem robust and they are probably the best attempt to date to unravel the carbon pathways in sediments at the Goban Spur area.

\subsection{Impact of the biota on benthic-pelagic fluxes}

Whereas the sinking of organic matter through the water column may be mainly a physical process, once the organic matter enters the benthic boundary layer, its fate is to a large extent controlled by the benthic animals. Mesocosm experiments showed that during summer, even under supercritical flow conditions with erosion, the macrofauna was able to reduce phytodetritus and POC from the BBL with a 50-60\% higher rate than sediments of similar bottom roughness without macrofauna (Thomsen and Flach, 1997). Such conditions prevailed on the upper part of the slope, where relatively high current velocities were measured in the bottom water, with an average of $9 \mathrm{~cm} \mathrm{~s}^{-1}$ in spring/summer and $37 \mathrm{~cm} \mathrm{~s}^{-1}$ in autumn/winter (Thomsen and van Weering, 1997, where also long-term observations on hydrodynamical conditions are reported) and where sediment accumulation rates were very low (van Weering et al., 1998). The feeding guilds at this depth were dominated by suspension feeders in the macrofauna, megafauna and even in the foraminiferans (Flach et al., 1998; Table 6), and these animals feed on particles that would otherwise remain in the water column. Sediment community oxygen consumption rates in this area of the Goban Spur were in the usual range for this water depth despite the high current velocities (Duineveld et al., 1997; Middelburg et al., 1997), demonstrating the importance of biodeposition. Organic carbon that would normally pass this area is trapped by the fauna and deposited in the sediment. In the other areas of the Goban Spur, the physical conditions were less adverse to settling and suspension feeders were not as prominent (Table 6).

Nevertheless, none of the environmental variables measured in the water $5 \mathrm{~cm}$ above the bottom showed the same range of variability as the density of filter- and interface-feeders (Fig. 3). The latter varied over more than an order of magnitude across the depth gradient, whereas the environmental variables varied by a factor 2-3 at most. Most probably the POC, CPE and (a fortiori) the TPM measured in the benthic boundary layer reflect what remains after the feeding activity of the filter-and interface-feeders, rather than what arrives in the benthic boundary layer. If the material arriving is a mixture of highly degradable organic material that is easily taken up and digested, and a refractory fraction that has a long residence time in the BBL, then the bulk of

Table 6

Estimated turnover time (\% per day) of carbon in biota and total mineralisable carbon in the sediment

\begin{tabular}{lclllllll}
\hline Station & Depth & Micro & Meio & Macro small & Macro large & Mega & Biota total & Cmin \\
\hline A & 208 & 0.43 & 3.36 & 2.80 & 0.59 & 0.23 & 0.76 & 0.82 \\
I & 670 & 0.24 & 3.51 & 2.32 & 0.72 & 0.19 & 0.49 & 0.24 \\
B & 1034 & 0.37 & 3.47 & 1.65 & 0.37 & 0.15 & 0.56 & 0.08 \\
II & 1425 & 0.24 & 3.06 & 1.89 & & 0.14 & 0.29 & \\
F & 2182 & 0.42 & 2.30 & 1.28 & & 0.10 & 0.48 & \\
III & 3670 & 0.38 & 2.62 & 0.91 & 0.07 & 0.40 & 0.03 \\
E & 4460 & 0.27 & 2.91 & 1.47 & 0.22 & 0.10 & 0.30 & \\
\hline
\end{tabular}


the material present will belong to the refractory fraction, even if the latter is only a small fraction of the arriving flux. This is comparable to the difference between organic flux and organic content of the sediment (see below). The nearly significant $(p=0.06)$ partial correlation (corrected for station depth) between CPE and density may reflect the generally shorter residence time of the chloroplastic pigments in the BBL; the degradable fraction in the pigment pool may be relatively more important than in the POC pool.

Even at the more quiescent stations along the Goban Spur transect, animals may increase the net flux of organic matter to the sediment. Soetaert et al. (1996c) were able to demonstrate that large animals, by injecting particles directly at depth into the sediment, significantly impacted activity versus depth profiles of the radionuclide ${ }^{210} \mathrm{~Pb}$ in the Goban Spur area. This biodeposition phenomenon was shown to be most prominent on the shelf and upper slope (up till a depth of $1425 \mathrm{~m}$ ), in accordance with the prominence of larger animals there. Similarly, it was argued that the presence of subsurface maxima in the nitrogen versus depth profiles in the two shallowest stations of the Goban Spur could reflect the importance of relocating organic matter from the surface directly into deeper layers of the sediment (Soetaert et al., 1997).

Apart from biodeposition effects, movement and feeding activity of benthic animals may affect the distribution of particles within the sediment and the substances that are required for animal growth may be handled preferentially. This may lead to a discrepancy between the so-called bulk mixing coefficients reflecting mixing of more long-lived sediment compounds, such as those based on ${ }^{210} \mathrm{~Pb}$, or those derived from tracers preferentially absorbed to fresh particles such as ${ }^{234} \mathrm{Th}$ (Smith et al., 1993; Middelburg et al., 1997). The difference between bulk sediment mixing rates and mixing intensity of food-related particles in the sediments of the Goban Spur may be evaluated by comparing ${ }^{210} \mathrm{~Pb}$-derived bioturbation coefficients (Soetaert et al., 1996c) with organic matter mixing rates, obtained by diagenetic modelling (Soetaert et al., 1998; Herman et al., 2001). Results (Fig. 6) show a three-order-of-magnitude difference between sediment mixing intensity based on ${ }^{210} \mathrm{~Pb}$ along the transect, whereas organic carbon mixing intensity varies with a factor of 5 at most. Both values of the mixing coefficient are of comparable magnitude at the shelf station, but diverge substantially at greater depth.

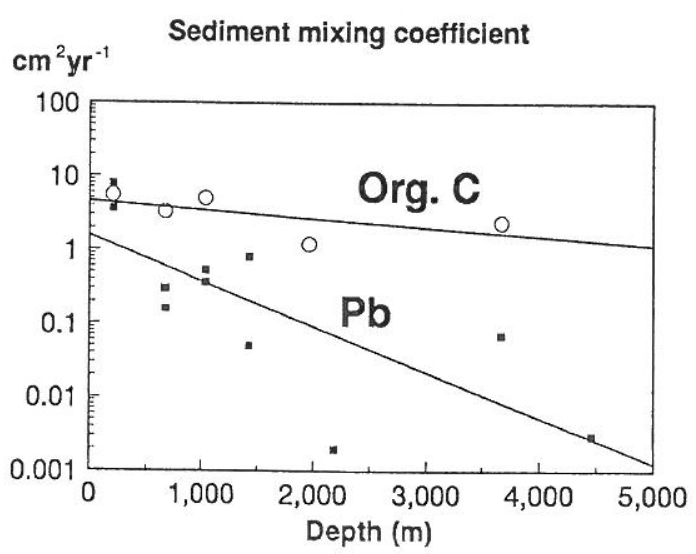

Fig. 6. Bulk sediment mixing coefficient, based on ${ }^{210} \mathrm{~Pb}$ (Soetaert et al., 1996c) and mixing intensity of organic carbon versus water depth. 


\subsection{Carbon flows through the benthic communities}

Benthic animals feed from organic matter derived, either directly or indirectly, from the euphotic zone. After ingestion, part of the food is used for respiration, part of it is egested as faeces or is excreted, the remainder (if any) is then diverted into somatic or reproductive growth. Simplified, the latter terms can be considered as repackaging of organic matter in a different form (faeces, dissolved organic matter or new animal biomass), which may be food for other organisms. As such, organic matter may cycle several times through the benthic food chain. In contrast, respiration transforms organic carbon into carbon dioxide, which is (largely) unavailable for further consumption. When there is no annual build-up or export of organic matter, the yearly integrated total system respiration, expressed in carbon units, must thus equal the flux of organic
matter minus the burial flux.

Not all oxygen consumption is due to direct oxidation of organic matter. Some $20-30 \%$ of $\mathrm{SCOC}$ is due to nitrifying bacteria, which oxidise the ammonium liberated by the mineralisation process. The remaining part is associated with carbon respiration (about $1 \mathrm{M}$ of oxygen per mole of carbon), either directly through oxic respiration, or indirectly through reoxidation of reduced by-products of the anoxic mineralisation process (e.g., Soetaert et al., 1996a). Therefore, SCOC rates may be easily converted into total mineralisation or carbon respiration rates.

The contribution of the various benthic groups to total carbon respiration was distinctly different between the shelf and upper slope compared to the lower slope and abyssal plain (Fig. 5 below), and this has been simplified in Fig. 7. In the shallower part of the transect, metazoan animals accounted for more than $50 \%$ of the carbon respiration, whereas in the deeper regions, their share was reduced to about $20 \%$ or less. The remaining part may be ascribed to the microbiota and can be further subdivided. Part of the total system mineralisation may be due to the consumption of oxidants other than oxygen, such as nitrate, nitrite, manganese and iron oxides, sulphate, etc. (Heip et al., 1995), which is predominantly mediated by bacteria. The contribution of these suboxic and anoxic processes to total carbon mineralisation in the Goban Spur was assessed by diagenetic modelling by Lohse et al. (1998), Soetaert et al. (1998) and Herman et al. (2001). Some $20-25 \%$ of all carbon respiration can be attributed to these suboxic and anoxic processes at the shelf and upper slope of the Goban Spur $(<1100 \mathrm{~m}$, stations A, I, B), whereas at greater depths, less than $10 \%$ of total mineralisation is mediated by anoxic/suboxic bacteria (Fig. 7).

Only a limited number of studies have partitioned shelf and deep-sea respiration rates among different faunal groups (Table 7). For a 2100-m deep station in the nearby Bay of Biscay (NE Atlantic), Mahaut et al. (1995) estimated respiration of meio-, macro- and megabenthos based on weight-specific relationships and combined this with microbial respiration rates provided by Rowe and Deming (1985). The latter were considered to be minimal estimates by the authors and moreover, did not include respiration due to protozoans. Therefore, the respiration rates of microbiota and total community respiration are probably too low, and the values for this station should be considered approximate at best. Piepenburg et al. (1995) used shipboard SCOC measures in conjunction with weight-specific estimates for meio-, macro- and megafauna to arrive at a respiration budget for the shelf-upper slope of arctic stations (NW Barents Sea). Microbiota respiration was assessed as the difference between SCOC and meio- and macrofaunal respiration. By means of inverse modelling, Eldridge and Jackson (1993) estimated 


\section{Shelf/upper slope}

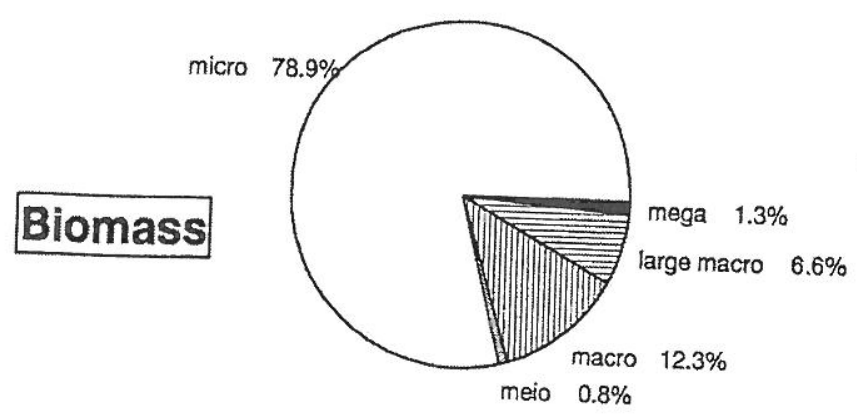

\section{Lower slope/abyssal plain}
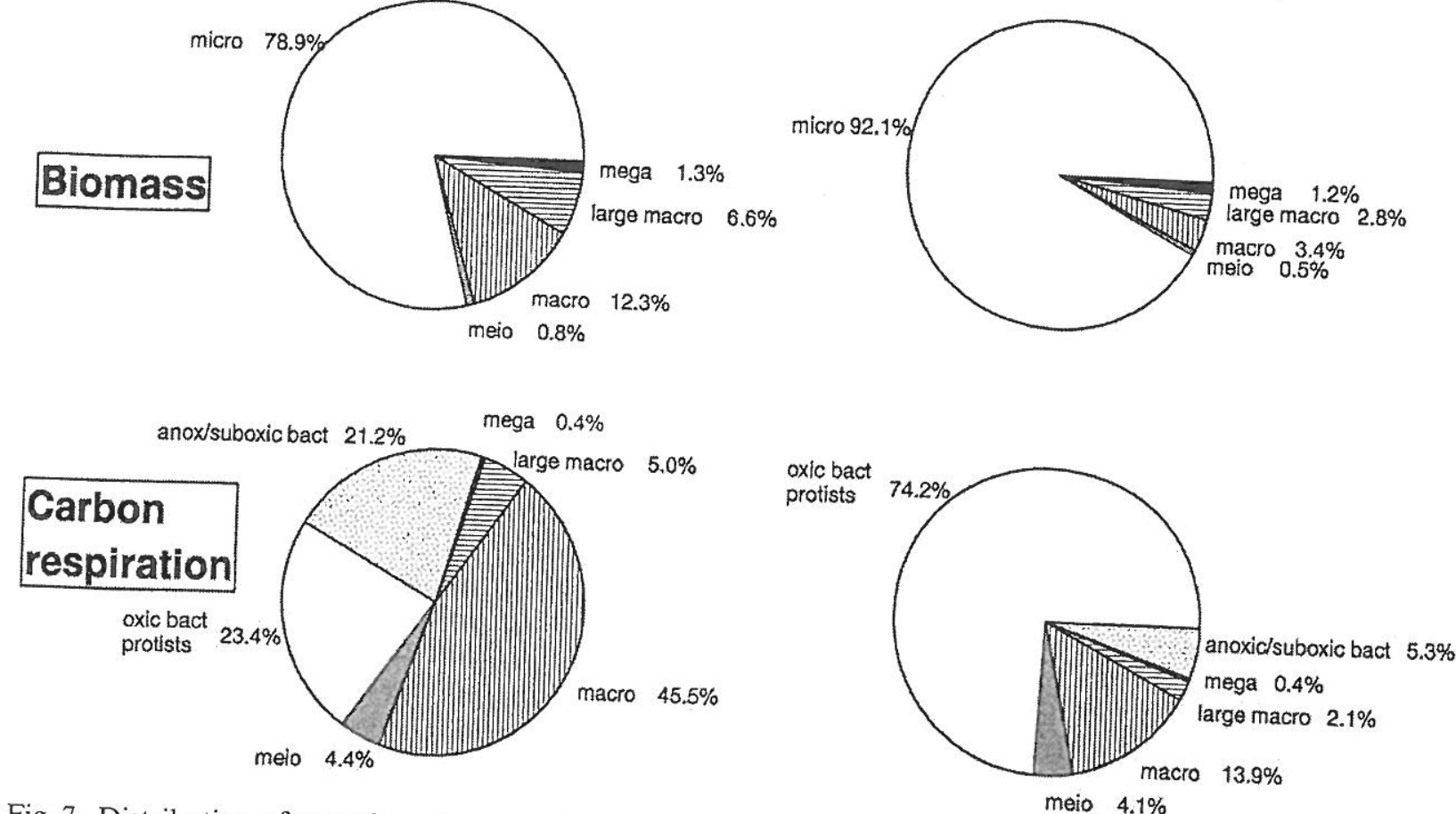

Fig. 7. Distribution of organic carbon over the various faunal groups (above) and partitioning of benthic respiration
(below) for shelf/upper slope (left) and lower slope stations (right).

Table 7

Contribution of different biota to total respiration ${ }^{\mathrm{a}}$

\begin{tabular}{|c|c|c|c|c|c|c|c|c|c|}
\hline Area & Reference & Depth (m) & $\begin{array}{l}\text { Temperature } \\
\left({ }^{\circ} \mathrm{C}\right)\end{array}$ & $\begin{array}{l}\text { Micro } \\
(\%)\end{array}$ & $\begin{array}{l}\text { Meio } \\
(\%)\end{array}$ & $\begin{array}{l}\text { Macro } \\
\text { small }(\%)\end{array}$ & $\begin{array}{l}\text { Macro } \\
\text { large }(\%)\end{array}$ & $\begin{array}{l}\text { Mega } \\
(\%)\end{array}$ & $\begin{array}{l}\mathrm{SCOC} \\
\mathrm{mgC} \mathrm{m}^{-2} \mathrm{~d}^{-1}\end{array}$ \\
\hline Arctic Ocean & $\begin{array}{l}\text { Piepenburg } \\
\text { et al. (1995) }\end{array}$ & $200-1010$ & $1-2$ & 47 & 8 & 26 & $15(3)$ & $4(3)$ & $31.5(1)$ \\
\hline OMEX upper slope & This study & $200-1030$ & $11-9$ & 44 & 4 & 46 & 5 & 0.4 & 27.0 \\
\hline OMEX lower slope & This study & $1460-4460$ & $7-2$ & 79 & 4 & 13 & 2 & 0.4 & 11.4 \\
\hline Bay of Biscay & $\begin{array}{l}\text { Mahaut et al. } \\
\text { (1995) }\end{array}$ & 2100 & 2 & 30 & 39 & 26 & & 5 & 4.0 \\
\hline $\begin{array}{l}\text { California Patton } \\
\text { escarpment }\end{array}$ & $\begin{array}{l}\text { Eldridge } \\
\text { and Jackson } \\
(1993)(4)\end{array}$ & 3700 & & 65 & 22 & 13 & & & 13.6 \\
\hline
\end{tabular}

\footnotetext{
${ }^{\text {" }} \mathrm{S}$ (ediment)COC is called $\mathrm{B}$ (enthic)COC in this paper, because respiration by large macrofauna and megafauna is not measured by classical whole sediment oxygen uptake measurements.

mmonium.

Endobiotic megafauna, equal to large macrofauna; epifauna and fish, equal to our megafauna $32 \%$ aerobic
cteria, $7 \%$ anaerobic, $20 \%$ microfauna, $7 \%$ burial rate.
} 
biotic contribution to total respiration in a $3700-\mathrm{m}$ deep station on the Patton Escarpment
(California Basin).

The estimates for

for the arctic stations total respiration is due to min the same depth range (Piepenburg et al., 1995). Less than half of size groups. Similarly, the OMEX lower slope and $10 \%$ by meiofauna, the remainder by the larger deep station on the Patton Escarpment (Elope and abyssal stations compare favourably with the $60 \%$ of the organic matter is respired (Eldridge and Jackson, 1993). In both areas, more than However, the contribution of meiofauna microbiota, while the remainder is due to metazoans. compared to the OMEX area.

Thus the predominance of metazoan respiration on the shelf and upper slope, compared to prevalence of microbiota on the lower slope-abyssal plain, appears to be a phenomenon common to otherwise distinct areas of the ocean. However, the number of comparable studies is meagre and more research in this area is needed to substantiate this result.

\subsection{Characterising the organic matter in sediments of the Goban Spur}

There is a large discrepancy between the composition of organic matter arriving at the sediment surface and the organic matter in the sediment. This is because the more labile fraction of the input flux will be decomposed rapidly, whereas the more refractory compounds accumulate in the sediment. From the point of view of a biologist, the former fraction of organic matter is the most interesting, because it constitutes food for organisms. Geologists on the other hand are more interested in the refractory compounds, because of their predominance in the sedimentary record and because this fraction is involved in the burial flux and constitutes the long-term carbon sink.

For the Goban Spur area, it was argued that the organic matter is deposited on the sediment in a very fresh state (Soetaert et al., 1998; Herman et al., 2001), its reactivity decreasing about 5-fold from the shelf to the abyss. This may reflect to a certain extent the quality of food as experienced by filter feeders that capture their food from the water column. However, except for the upper part of the slope, the majority of benthic animals were deposit feeders (Flach et al., 1998) and their food is diluted with inert sediment grains. The concentrations of mineralisable organic carbon increase from $4.5 \mathrm{~g} \mathrm{C} \mathrm{m}^{-2}$ at the shelf to $38.5 \mathrm{~g} \mathrm{C} \mathrm{m}^{-2}$ at the abyssal station (Table 3 ). On the shelf there is thus about as much mineralisable carbon as organisms, whereas there is about 10 times more food than biotic biomass at the abyss. As the total flux of organic matter decreases with depth, the higher concentrations of organic matter at greater depth imply a strongly reduced of organic matter at the shelf is in the oriments; indeed, roughly estimated, the mean residence time (Table 5).

Rowe et al. (1991) compared biotic biomass and total organic carbon (upper $15 \mathrm{~cm}$ ) with sediment community oxygen consumption rates to evaluate the turnover time of biota and organic matter. They concluded that the turnover of biota occurred in a time span of months,
whereas the residence time of the sedimentary carbon was in the order of years to centuries. One
of the drawbacks of using total organic arb of the drawbacks of using total organic carbon concentrations is the dependence of the obtained turnover time on the depth of the sediment considered and on the sedimentary environment. Depth into the sediments relates to age by the sedimentation rate, hence, in rapidly settling 
sediments, the time window of $15 \mathrm{~cm}$ of sediment will be much smaller compared to sediments causing higher background carboner, with decreasing grain size, the sorption surface increases, coarser shallow sediments. The estimates of this drawback. Our values of "mineralisable" organic carbon used in our study do not suffer from organic matter contributing to the bisable" organic carbon estimate the amount of sedimentary TOC in the sediment. In contrast biogeochemical profiles of oxygen, nitrate, ammonium and disappeared at a certain depth into the sed organic carbon, the "mineralisable" organic matter has depth considered (as long as it is deep different sedimentation characteristics. Nough). This facilitates comparison among sites with results from Rowe et al. (1991). Benthic biomass, the results we obtain agree qualitatively with ranging from about $130 \mathrm{~d}$ at the shelf station to on the Goban Spur area had a residence time latter mainly due to the low turnover time of microbion than $300 \mathrm{~d}$ at station II at $\sim 1400 \mathrm{~m}$ (the ranged from $0.8 \% \mathrm{~d}^{-1}$ at the shelf station to $0.03 \% \mathrm{~d}^{-1}$ at the deepest of mineralisable carbon organic matter became more refractory with increasing water depth. The restation, and hence the matter was comparable to biotic residence time the shelf (about The residence time of organic whereas mineralisable carbon resided significantly longer (about $120 \mathrm{~d}$ compared to $130 \mathrm{~d}$ ), compared to $250 \mathrm{~d}$ ) at the deepest station.

\section{Acknowledgements}

This study was financially supported through the OMEX project (MAS2-CT93-0069 and MAS3-CT96-0056), and ship-time was funded by the Netherlands Geoscience Foundation GOA, NIOZ and the German Science Foundation DFG. This is publication no. 2557 of the Netherlands Institute of Ecology, Centre for Estuarine and Coastal Ecology.

\section{References}

Aller, R.C., 1984. The importance of relict burrow structures and burrow irrigation in controlling sedimentary solute distributions. Geochimica et Cosmochimica Acta 48, 1929-1934.

Andrassy, I., 1956. The determination of volume and weight of nematodes. Acta Zoologica (Hungarian Academy of
Science) 2 (1-3), 1-15.

Antia, A., Von Bodungen, B., Peinert, R., 1999. Particle flux at the mid- European continental margin. Deep-Sea
Research I 46, 1999-2024.

Berner, R.A., 1980. Early Diagenesis-A Theoretical Approach. Princeton University Press, Princeton, New York, 241 pp.

Bodungen, B. von, Wunsch, M., Fürderer, H., 1991. Sampling and analysis of suspended and sinking particles in the North Atlantic. Geophysical Monograph 63, 47-56. Boudreau, B.P., 1986. Mathematics of tracer mixing in sediments: I. Spatially dependent, diffusive mixing. American
Journal of Science 286, 161-198.

Boudreau, B.P., 1994. Is burial velocity a master parameter for bioturbation? Geochimica et Cosmochimica Acta 58 (4),
1243-1249.

Carey, D.A., 1983. Particle resuspension in the benthic boundary layer induced by flow around polychaete tubes. Canadian Journal of Fisheries and Aquatic Science 40 (Suppl. 1), 301-308.

Bovée, F., Labat, J.P., 1993. A simulat
PSZI Marine Ecology 14, 159-173. 
Duineveld, G.C.A., Lavaleye, M.S.S., Berghuis, E.M., de Wilde, P.A.W.J., van der Weele, J., Kok, A., Batten, S.D., de Leeuw, J.W., 1997. Patterns of benthic fauna and benthic respiration on the Celtic continental margin in relation to the distribution of phytodetritus. Internationale Revue der gesamten Hydrobiologie 82 (3), 395-424.

Eldridge, P.M., Jackson, G.A., 1993. Benthic trophodynamics in California coastal basin and continental slope communities inferred using inverse analysis. Marine Ecology Progress Series 99, 115-135.

Findlay, R.H., Dobbs, T.S., 1993. Quantitative description of microbial communities using lipid analysis. In: Kemp, P.F. (Ed.), Handbook of Methods in Aquatic Microbial Ecology. Lewis Publishers, Florida, pp. 271-284.

Flach, E., Heip, C., 1996a. Vertical distribution of macrozoobenthos within the sediment on the continental slope of the Goban Spur area (NE Atlantic). Marine Ecology Progress Series 141, 55-66.

Flach, E., Heip, C., 1996b. Seasonal variations in faunal distribution and activity across the continental slope of the Goban Spur area (NE Atlantic). Journal of Sea Research 36 (3/4), 203-215.

Flach, E., Lavaleye, M., de Stigter, H., Thomsen, L., 1998. Feeding types of the benthic community and particle transport across the continental slope of the Goban Spur. Progress in Oceanography 42, 209-231.

Flach, E., Thomsen, L., 1998. Do physical and chemical factors structure the macrobenthic community at a continental slope in the NE Atlantic? Proceedings of the 32nd EMBS, Lysekil, Hydrobiologia 375/376, 265-285.

Flach, E., Vanaverbeke, J., Heip, C., 1999. Meiofauna: macrofauna ratios along the continental slope of the Goban Spur (NE Atlantic) in relation to food availability. Journal of the Marine Biological Association of the United Kingdom 79, 233-241.

Gage, J.D., Tyler, P.A., 1991. Deep-sea biology: a natural history of organisms at the deep-sea floor. Cambridge University Press, Cambridge, 504pp.

Graf, G., Rosenberg, R., 1997. Bioresuspension and biodeposition: a review. Journal of Marine Systems 11, $269-278$.

Heip, C.H.R., Goosen, N.K., Herman, P.M.J., Kromkamp, J., Middelburg, J.J., Soetaert, K., 1995. Production and consumption of biological particles in temperate tidal estuaries. Oceanography and Marine Biology: an Annual Review 33, 1-149.

Heip, C., Vincx, M., Vranken, G., 1985. The ecology of marine nematodes. Oceanography and Marine Biology. Annual Review. London 23, 399-489.

Herman, P.M.J., Soetaert, K., Middelburg, J.J., Heip, C., Lohse, L., Epping, E., Helder, W., Antia, A.N., Peinert, R., 2001. The seafloor as the ultimate sediment trap-using sediment properties to constrain benthic-pelagic exchange processes at the Goban Spur. Deep-Sea Research II 48, 3245-3264.

Joint, I., Wollast R., Chou, L., Batten, S., Elskens, M., Edwards, E., Hirst, A., Burkill, P., Groom, S., Gibb, S., Miller, A., Hydes, D., Dehairs, F., Antia, A., Barlow, R., Rees, A., Pomroy, A., Brockmann, U., Cummings, D., Lampitt, R., Loijens, M., Mantoura, F., Miller, P., Raabe, T., Alvarez-Salgado, X., Stelfox C., Woolfenden, J., 2001. Pelagic production at the Celtic Sea shelf break. Deep-Sea Research II 48, 3049-3081.

Jumars, P.A., Nowell, A.R.M., 1984. Effects of benthos on sediment transport: difficulties with functional grouping. Continental Shelf Research 3 (2), 115-130.

Lohse, L., Helder, W., Epping, E.H.G., Balzer, W., 1998. Recycling of organic matter along a shelf-slope transect across the NW European Continental Margin (Goban Spur). Progress in Oceanography 41, 77-110.

Lorenzen, C.J., 1967. Determination of chlorophyll and phaeopigments: spectrophotometric equations. Limnology and Oceanography $12,343-346$.

Mahaut, M.-L., Sibuet, M., Shirayama, Y., 1995. Weight-dependent respiration rates in deep-sea organisms. Deep-Sea Research I 42, 1575-1582.

Middelburg, J.J., Soetaert, K., Herman, P.M.J., 1997. Empirical relationships for use in global diagenetic models. Deep-Sea Research I 44, 327-345.

Miller, D.C., Jumars, P.A., Nowell, A.R.M., 1984. Effects of sediment transport on deposit feeding: Scaling arguments. Limnology and Oceanography 29 (6), 1202-1217.

Piepenburg, D., Blackburn, T.H., von Dorrien, C.F., Gutt, J., Hall, P.O.J., Hulth, S., Kendall, M.A., Opalinski, K.W., Rachor, E., Schmidt, M.K., 1995. Partitioning of benthic community respiration in the Arctic (northwestern Barents Sea). Marine Ecology Progress Series 118, 199-213.

Rowe, G.T., 1983. Biomass and production of deep-sea macrobenthos. In: Rowe, G.T. (Ed.), The Sea, Vol. 8. Wiley, New York, pp. 97-121. 
Rowe, G.T., Deming, J.W., 1985. The role of bacteria in the turnover of organic carbon in deep-sea sediments. Journal
of Marine Research 43, 925-950.

Rowe, G., Sibuet, M., Deming, J., Khripounoff, A., Tietjen, J., Macko, S., Theroux, R.', 1991. Total' sediment biomass and
preliminary estimates of organic carbon residen

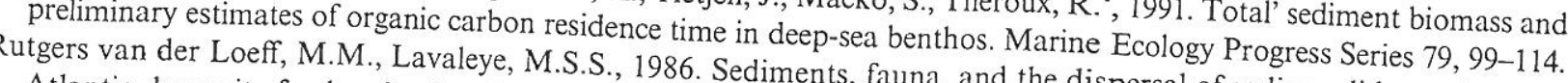
Atlantic dumpsite for low-level radioactive waste. Rediments, fauna, and the dispersal of radionuclides at the N.E. Sea Research, 134 pp.

Smith, C.R., Pope, R.H., DeMaster, D.J., Magaard, L., 1993. Age-dependent mixing of deep-sea sediments. Geochimica et Cosmochimica Acta 57, 1473-1488.

Soetaert, K., Herman, P.M.J., Middelburg, J.J., 1996a. A

depths. Geochimica et Cosmochimica Acta 60 (6), 1019-1040.

Soetaert, K., Herman, P.M.J., Middelburg J J (6), 1019-1040.

A model. Limnology and Oceanography 41 (8), 1651-1668.

Soetaert, K., Herman, P.M.J., Middelburg, J.J., Heip, C., 1998

and mixing rate in an ocean margin sediment (Northeast Assessing organic matter mineralization, degradability Research 56 (2), 519-534.

Soetaert, K., Herman, P.M.J., Middelburg J.J., Heip, C.M., Helder, W., 1996c. Modelling ${ }^{210} \mathrm{~Pb}$-derived mixing activity in ocean margin., van Weering, T.C.E., Epping, E., mixing. Journal of Marine Research 54, 1207-1227.

Soetaert, K., Vanaverbeke, J., Heip, C., Herman, P M. distribution in ocean margin sediments of the Goban Siddelburg, J.J, Duineveld, G., Sandee, A., 1997. Nematode geochemistry. Deep-Sea Research 44, 1671-1683.

Sokal, R.R., Rohlf, F.J., 1995. Biometry. The principles ant Freeman, New York, 887pp.

Soltwedel, T., 1997. Temporal variabilities in Oceanologica Acta 20, 871-879.

Taghon, G.L., Greene, R.R., 1992. Utilization of deposited and sus feeders. Limnology and Oceanography 37 (7), 1370-1391.

Tahey, T.M., Duineveld, G.C.A., Berghuis 37 (7), 1370-1391.

of the benthos and Phytopigments along the Nor, P.A.W.J., 1996. Sediment $\mathrm{O}_{2}$ demand, density and biomass Oceanologica Acta 19, 117-129.

Thomsen, L., Flach, E., 1997. Mesocosm observations of fluxes of particulate Journal of Sea Research 37, 67-79.

Thomsen, L., Graf, G., Martens, V., Steen, E., 1994. An instrument for sampling water from the benthic boundary
layer. Continental Shelf Research 14 (7/8), 871-882. Thomsen, L., van Weering, Tj.C.E., 1997 .

boundary layer at the NW European Continental margin (Celtic Sea). Prority of particulate matter in the benthic

Vanaverbeke, J., Soetaert, K., Heip, C., Vanreusel, A., 1997. The meiobenthos aress in Oceanography 42, 61-76.

Spur (NE Atlantic). Journal of Sea Research 38 (1-2), 93-108.

van Weering, Tj.C.E., 1994. Cruise report OMEX, 18/5-13/6 1994,

van Weering, Tj.C.E., Hall, I.R., Stigter, H.C. de, McCa/ 18/5-13/694, with R.R.S. 'Charles Darwin', pp. 28.

accumulation and carbon burial at the Goban Spur, N.W. Eu., Thomsen, L., 1998. Recent sediments, sediment

Oceanography 42, 5-36.

van Weering, Tj.C.E., De Stigter, H.C., Balzer, W., Epping, E.H.G., Graf, G., Hall, IR., Helder, W., Khripounoff, A., Lohse, L., McCave, I.N., Thomsen, L., Vangriesheim, A., 2001. Benthic dynamics and carbon fluxipounoff, A.,

European continental margin. Deep-Sea Research II 48, 3191-3221.
Wassmann, P., 1990. Relationship between primary and export production in the boreal and carbon fluxes in the NE

Atlantic. Limnology and Oceanography 35, 464-471.

Wheatcroft, R.A., Jumars, P.A. Smith, C.R.,

coefficient: step lengths, rest periods and transport directions. Journal of Marine Research $48,177-207$.

Winberg, G.G., 1971. Methods for estimation of production of Journal of Marine Research 48, 177-207. 
$\because$ 